\title{
Religious Discourse in the Public SquARe
}

\author{
David Blaikie and Diana Ginn
}

\section{INTRODUCTION}

Full, open, and civilized discourse among citizens is fundamental to the life of a liberal democracy. It seems trite to assert that no discourse should be prohibited or excluded simply because it is grounded in religious faith or employs religious beliefs to justify a particular position. ${ }^{1}$ Yet there are those who contend that it

We realize that we cannot do full justice in an article of this length to the issues that we raise here. We see this article as allowing us to provide an introduction to and overview of the topic and to organize our thoughts around some of the key points. We will then explore these issues in greater depth, as is warranted by their complexity, in our future work. The focus of our article is not simply "the bases on which citizens rely in making political choices but also the bases on which citizens may and should rely in justifying political choices." Michael J. Perry, Love and Power: The Role of Religion and Morality in American Politics (New York: Oxford University Press, 1991) at 17 [Perry, Love and Power]. Our references in this article are primarily to Christianity or, some-times, the combined JudeoChristian tradition. There are two reasons for this focus. First, where we refer to religious influences on the development of the Western legal tradition, it is accurate to focus on the JudeoChristian tradition as the religious tradition that has most heavily influenced that development. We would suggest that much the same relationship exists between the Judeo-Christian tradition and the Western legal system as Northrup Frye suggested exists between the Bible and Western literature. In Words With Power (Markham: Penguin Books Canada Ltd., 1990) [Frye, Words]. Frye builds on ideas initially developed in The Great Code: The Bible and Literature (Toronto: Academic Press, 1982), arguing (Words, ibid. at xi) that "the structure of the Bible, as revealed by its narrative and imagery" has shaped the "conventions and genres of Western literature." Of course, it is quite possible that future legal developments will reflect the growing religious pluralism of Canada. Second, where we give examples to elaborate on a particular point, these relate primarily (although not exclusively) to Christianity because we are writing out of our own experiences and backgrounds. This is the only religious tradition in which we have worshipped and about which we feel knowledgeable enough to comment in any depth. However, we do not want to be misunderstood as making arguments only about religious discourse based on Christian beliefs. It is our position that spirituality continues to be of importance for many individuals today; that for many such individuals, their religious beliefs undergird their political views; and that explicit references to those beliefs is an appropriate part of public discourse. This position applies to all religions, not just Christianity. As the homogeneity of Canada's is improper for citizens to use religious arguments when debating or deciding issues in the public square, ${ }^{2}$ that metaphorical arena where issues of public policy are discussed and contested. In this article we challenge this position, examining the various arguments that are put forward for keeping public discourse secular, arguments that when citizens explicitly ground their social and political views in their religious beliefs, this is divisive, exclusionary, and ultimately antithetical to the liberal democratic state. We maintain that none of these arguments are persuasive. ${ }^{3}$

religious landscape is leavened by immigrants bringing deep religious roots in a variety of different faith traditions, it seems likely that the religious reasons relied on in public debates will more and more reflect this diversity.

2 Our discussion draws primarily on American writings on this topic, and in particular Robert Audi \& Nicholas Wolterstorff, Religion in the Public Square (New York: Rowman \& Littlefield, 1997) [Audi \& Wolterstorff].

3 There was a time in Western society when religion played a far more overt role in shaping public policy and law than is the case today. Duncan Forrester suggests that "in the past a theological approach, or at least an explicitly theological dimension to the discussion, was almost universal in western political thought .... The political significance of theology was almost universally assumed." Christian Justice and Public Policy (Cambridge: Cambridge University Press, 1997) at 10. In the world of medieval Europe, for instance, it was thought natural and inevitable that Christian theology would mould secular as well as ecclesiastic law, both in terms of how law itself was conceptualized and in the specific content of the law. While the political significance of theology is no longer universally assumed, the law in Canada today still bears the imprint of that earlier time. In Law and Revolution: The Formation of the Western Legal Tradition, Harold J. Berman makes a convincing argument that the "basic institutions, concepts, and values of Western legal systems have their sources in religious rituals, liturgies, and doctrines of the eleventh and twelfth centuries" (Cambridge: Harvard University Press, 1983) at 165 [Berman, Law and Revolution]. According to Berman, reforms initiated by the Roman Catholic Church in medieval Europe that are still foundational to our legal system include: the introduction of rational trial procedures to replace magical mechanical modes of proof by ordeals of fire and water, by battles of champions, and by ritual oaths; the insistence upon consent as the foundation of marriage and upon wrongful intent as the basis of crime and the development of equity to protect the poor and the helpless against the rich and the powerful and to enforce relations of 
Religion continues to be important to a significant number of Canadians. In the 2001 census, 16 percent of the population declared themselves as having no religion. ${ }^{4}$ This means that over 80 percent of Canadians consider themselves to have some religious beliefs, whether this means an affiliation to an established faith tradition or simply a sense of the spirituality inherent in life. Various observers of today's culture argue that many Canadians are in fact deeply interested in spiritual matters. ${ }^{5}$

We would argue that, for many religious believers, their faith (whatever that faith may be) is the lens through which they view any issue of significance, including legal issues, and that there are no convincing reasons to characterize religious-based arguments as an illegitimate form of public discourse. It may be that explicit identification of one's religious views as the source for one's social values is less frequent today in the Western world (at least in part,

trust and confidence. See Harold J. Berman, Faith and Order: The Reconciliation of Law and Religion (Atlanta: Scholars Press, 1993) at 4 . Other, less progressive examples can also be found. For instance, in the past, the restricted legal status of women within marriage and the exclusion of women from public life were no doubt influenced in part by the dominant Christian theology of the day. We would note tangentially here that a knowledge of (even if not necessarily a belief in) the basic tenets of Judaism and Christianity will provide insight into the historical development of Canada's laws. Presumably a knowledge of other religions would contribute to an understanding of other legal traditions. Thus, it seems likely that studying the basic tenets of Hinduism might well be relevant to understanding how law developed in India; understanding Confucianism might well illuminate one's understanding of law in China, at least until the time of the Chinese Revolution.

Statistics Canada, "Population by Religion, by Provinces and Territories," 2001 Census, online: <http://www.statcan.ca/ english/Pgdb/demo30a.htm $>$. There were significant regional variations, from a mere 2.5 percent of Newfoundlanders reporting themselves as being of no religion to 35 percent and 37 percent in British Columbia and Yukon, respectively.

In his most recent book, Restless Gods: The Renaissance of Religion in Canada (Toronto: Stoddart Publishing Co., 2002), sociologist Reginald Bibby states, "It's time we said it: when it came to predicting the future of religion generally and Christianity specifically, Karl Marx, Emile Durkheim, and Sigmund Freud were wrong. Societies and individuals have not ceased to have a need for religion." Quoted in Jim Coggins, "No Longer Interested?" online: Encounter $<$ http://www.encountergod.com/20/interested.html>. In 1999, George Gallup stated: "There is a searching for spirituality and a hunger for God such as we have not seen in 65 years of scientific polling." Quoted in Dr. Ian Ritchie, "Spirituality on the March," online: <http://www3.sympatico.ca/ian.ritchie/ Secularization.htm>. perhaps, because such discourse has been delegitimized by some modern theorists). It nevertheless seems logical and in fact inevitable that, as long as religious beliefs persist, ${ }^{6}$ some individuals will want to make religious-based arguments on matters of law and public policy.

This should not be surprising, given the nature of religion and of law. Both involve a belief that there are right ways and wrong ways of living in community with others. Both involve some vision of what a "just society" or the "Kingdom of God" should look like - even if there is intense disagreement within a society or within a religion as to the content of this vision. Therefore, for many people of faith, discerning the religious dimension in questions of law and public policy is a vital part of determining their response to those questions. In fact, for anyone who sincerely believes that religious faith involves a journey tow ard understanding and acting upon God's will, how could the insights gained throughout that journey not affect one's views on many issues of legal and constitutional significance? And why, if engaged in public deliberation on or justification of those views, would one not articulate those insights? ${ }^{7}$ As Richard Moon notes:

${ }^{6}$ Karen Armstrong suggests:

$[\mathrm{H}]$ uman beings are spiritual animals. Indeed, there is a case for arguing that Homo sapiens is also Homo religiosus. Men and women started to worship gods as soon as they became recognisably human; they created religions at the same time as they created works of art. This was not simply because they wanted to propitiate powerful forces but these early faiths expressed the wonder and mystery that seems always to have been an essential component of the human experience of this beautiful yet terrifying world. Like art, religion has been an attempt to find meaning and value in life, despite the suffering that flesh is heir to. Like any other human activity, religion can be abused but it seems to have been something that we have always done. It was not tacked on to a primordially secular nature by manipulative kings and priests but was natural to humanity.

A History of God (London: Heinemann, 1993) at 3. Issues that religious believers might see as particularly affected by their faith include: same-sex marriage (e.g., Halpern v. Canada (Attorney General) (2003), 225 D.L.R. (4 $\left.4^{\text {th }}\right) 529$ (Ont. CA), online: CanLII <http://canlii.org/on/cas/onca/2003/ 2003 onca $10102 . \mathrm{html}>$ ); assisted suicide (e.g., Rodriguez v. British Columbia (Attorney General), [1993] 3 S.C.R. 519, online: CanLII <http://www.canlii.org/ca/cas/scc/1993/ 1993scc101.html>); abortion (e.g., R. v. Morgentaler, [1988] 1 S.C.R. 30, online: CanLII <http://www.canlii.org/ca/cas/scc/ 1988/1988scc2.html $>$ ); new genetic technologies (e.g., Harvard 
While we may seek to minimize direct religious conflict and confrontation in public life, we must also recognize that religious commitment has implications for how adherents should live their lives in the larger community and for the kind of society they should work to create. ${ }^{8}$

Yet, the legitimacy of religious-based discourse in the public square is far from universally accepted by academic writers, and so we move to the main focus of this article: responding to arguments that would exclude such discourse from public policy discussion and decision-making. Before we do so, however, we pause to point out that we are not arguing that religious-based discourse will always move us in

College v. Canada (Commissioner of Patents), [2002] 4 S.C.R 45, 2002 SCC76, online: CanLII <http://www.canlii.org/ $\mathrm{ca} / \mathrm{cas} / \mathrm{scc} / 2002 / 2002 \mathrm{scc} 76 . \mathrm{html}>$ ); the prohibition on discrimination in human rights or constitutional law, as well as legal exceptions to that prohibition; the extent to which our system of taxation should redistribute resources; whether the criminal law should be aimed at retribution or rehabilitation; and how the secular law should apply to the ordering of relationships within a religious community or between that community and others in society. This last issue encompasses a wide variety of questions. For instance, do human rights law, labour law, and administrative law apply to the hiring, terms of employment, or dismissal of clergy? See, e.g., McCaw v. United Church of Canada (1991), 4 O.R. 3d 481 (CA). Can a religious school impose religious-based requirements on students or teachers? See, e.g., Vriend v. Alberta, [1998] 1 S.C.R. 493, online: CanLII < http://www.canlii.org/ca/cas/scc/ 1998/1998scc30.html>; and Trinity Western University v. British Columbia College of Teachers, [2001] 1 S.C.R. 772, 2001 SCC31, online: CanLII $<$ http://canlii.org/ca/cas/scc/2001/ $2001 \mathrm{scc} 31 . \mathrm{html}>$ [Trinity Western]. Can a school, whether public or with religious affiliations, refuse, on religious grounds, to use certain texts as teaching materials or to have those texts in the school library? See, e.g., Chamberlain $v$. Surrey School District No. 36, [2002] 4 S.C.R. 710, 2002 SCC 86, online: CanLII <http://www.org/ca/cas/scc/2002/2002 scc86.html $>$ [Chamberlain]. What happens when child welfare law conflicts with a religious community's views on raising children? Can parents refuse life-saving medical treatment for their child if the treatment is prohibited by their religious beliefs? See, e.g., R.B. v. C.A.S. of Metropolitan Toronto, [1995] 1 S.C.R. 315, online: CanLII <http://www.canlii. org/ca/cas/scc/1995/1995 scc7. html>. How does the law respond if, on separation or divorce, parents are in disagreement as to the religious education of their children? See, generally, on these issues, M.H. Ogilvie, Religious Institutions and the Law in Canada, $2 \mathrm{~d}$ ed. (Toronto: Irw in Law, 2003). On any one of these issues, and myriad others, it would be difficult for people of faith to arrive at a conclusion without reference to their religious beliefs.

8 Richard Moon, "Liberty, Neutrality and Inclusion: Religious Freedom Under the Canadian Charter of Rights and Freedoms" 41 Brandeis Law Journal 563 at 573 [Moon]. the direction of justice and compassion. ${ }^{9}$ Nor would we think it persuasive for those who would exclude religious-based arguments from public discussion to seek to justify their position by maintaining that the influence of religion on society has been or will be consistently negative.

\section{THE LEGITIMACY OF RELIGIOUS DISCOURSE IN THE PUBLIC SQUARE}

We suggested above that as long as religious beliefs persist, some individuals will want to make religious-based arguments on matters of law and public policy. This being the case, are there valid reasons for keeping such discourse out of the public square? As we examine the various arguments that have been put forth for keeping public policy discussion secular, ${ }^{10}$ it is our view

9 Thus, we would not join with Paul Horwitz, "The Sources and Limits of Freedom of Religion in a Liberal Democracy: Section 2(a) and Beyond" (1996) 54 University of Toronto Faculty Law Review 1 [Horwitz], arguing that "religion is an intrinsic good" (at 55) or that "as an intuitive proposition it [the idea that religion is intrinsically good] is both clear and compelling. Even those who lack religious faith can understand the ineffable and invaluable quality of religious commitment" (at 56). We do not take this position for at least two reasons. First, Horwitz's assumption that this proposition is compelling seems doubtful; it is unlikely that those who have consciously discarded the religious beliefs in which they were raised (and not replaced these with another set of religious beliefs) would find arguments about the intrinsic good of religion to be compelling. Second, Horwitz's assumption seems insufficiently nuanced to deal with the variations among and complexities of the beliefs (and ensuing behaviours) that could be labeled "religious."

10 While we respond in this paper to arguments advanced by secular thinkers as to why religion should be kept private and why the public square should be kept secular, it is only fair to note that some religious believers would also argue that religion and politics do not mix; that spirituality means keeping one's eye firmly on the life to come or on one's inner consciousness, rather than on the realities of everyday life. The fact that some believers may wish to limit their engagement with or withdraw from public life does not, however, end the discussion, since this is far from a universal characteristic of those with religious beliefs. There will always be those whose faith calls them into action in this world. The prophetic role of faith has strong roots in the Jewish and Christian traditions. It embodies an understanding of the "Kingdom of God" as something to be worked for here on earth, rather than simply anticipated either after death or at the end of the world. Clearly too, a quest for social justice has strong roots in Islam. It seems likely that other faith communities also encompass a sense of the transformative role of religion in civil society. Perry suggests that: "Partly in consequence of mutually transformative ecumenical encounter and dialogue with one or more of the semitic religions, Indic spiritualities-in particular, Hinduism and Buddhism-are retrieving from their margins their prophetic resources." Perry, Love and Power, supra note 1 at 81 [footnotes omitted]. 
that, these arguments, whether taken separately or in combination with each other, are simply not convincing. ${ }^{11}$

Arguments for keeping religious discussion separate from public policy discussions are founded on beliefs about the nature of a secular state or, more specifically, the nature of liberal democracy. ${ }^{12}$ Wolterstorff describes the liberal position: "[C]itizens (and officials) are not to base their decisions and/or debates concerning political issues on their religious convictions. ${ }^{13}$ Of course,

11 Those in favour of constraints on religious discourse in the public square include: Robert Audi, Religious Commitment and Secular Reason (New York: Cambridge University Press, 2000); Robert Audi, "The Place of Religious Argument in a Free and Democratic Society" (1993) 30 San Diego Law Review 677; Kent Greenawalt, Religious Convictions and Political Choice (New York: Oxford University Press, 1988) [Greenawalt, Religious Convictions]; Kent Greenawalt, "Grounds for Political Judgment: The Status of Personal Experience and the Autonomy and Generality of Principles of Restraint" (1993) 30 San Diego Law Review 647 [Greenawalt, "Grounds for Political Judgment"]; William P. Marshall, "The Other Side of Religion" (1993) 44 Hastings Law Journal 843 Suzanna Sherry, "The Sleep of Reason" (1996) 84 Georgetown Law Journal 453; and John Rawls, Political Liberalism (New York: Columbia University Press, 1993) [Rawls]. Those arguing against limits include: Larry Alexander, "Liberalism, Religion and the Unity of Epistemology" (1993) 30 San Diego Law Review 763 [Alexander]; Jonathan Chaplin, "Beyond Liberal Restraint: Defending Religiously-Based Arguments in Law and Public Policy" (2000) 33 University of British Columbia Law Review 617 [Chaplin]; Frederick M. Gedicks, "Public Life and Hostility to Religion" (1992) 78 Virginia Law Review 671; Frederick M. Gedicks, "The Religious, the Secular, and the Antithetical" (1991) 20 Capital University Law Review 113 [Gedicks]; David Hollenbach, "Contexts of the Political Role of Religion: Civil Society and Culture" (1993) 30 San Diego Law Review 877; Michael W. McConnell, "Five Reasons to Reject the Claim That Religious Arguments Should Be Excluded from Democratic Deliberation" (1999) Utah Law Review 639; Perry, Love and Power, supra note 1; Michael J. Perry, "Religious Morality and Political Choice: Further Thoughts - and Second Thoughts - On Love and Power" (1993) 30 San Diego Law Review 703; Steven Shiffrin, "Propter Honoris Respectum: Religion and Democracy" (1999) 74 Notre Dame Law Review 1631; and Michael Walzer, "Drawing the Line: Religion and Politics" (1999) Utah Law Review 619. For an interesting debate on the issue, see Audi \& Wolterstorff, supra note 2 .

12 Arguably, the wide acceptance of these arguments may also in some instances reflect lack of knowledge about religion, which according to David Tracy, "is the single subject about which many intellectuals can feel free to be ignorant. Often abetted by the churches, they need not study religion, for 'everybody' already knows what religion is: It is a private consumer product that some people seem to need. Its former social role was poisonous. Its present privatization is harmless enough to wish it well from a civilized distance." Quoted in Perry, Love and Power, ibid. at 67.

13 Audi \& Wolterstorff, supra note 2 at 73 . When referring to the "liberal position" we are referring to what Michael J. Sandel describes as: no one proposes that religious argument by citizens in the public square should be illegal. ${ }^{14}$ The thrust of the liberal position is that people of faith should voluntarily abstain from basing their public policy decisions on religious grounds or from making religiously based arguments. This is much the position of Robert Audi, who argues that "[a]s advocates for laws and public policies ... and especially for those that are coercive, virtuous citizens will seek grounds of a kind that any rational adult citizen can endorse as sufficient for the purpose."15 John Rawls argues for the exclusion of religious or other comprehensive philosophies in favour of what he calls "public reason" in discussing and deciding "constitutional issues" and "matters of basic justice." 16 Richard Rorty sounds a note of urgency, stating that "[c]ontemporary liberal philosophers think that we shall not be able to keep a democratic political community going unless the religious believers remain willing to trade privatization for a guarantee of religious liberty."

\begin{abstract}
a version of liberalism prominent in the moral and legal and political philosophy of the day.... Its core thesis can be stated as follows: society, being composed of a plurality of persons, each with his own aims, interests, and conceptions of the good, is best arranged when it is governed by principles that do not themselves presuppose any particular conception of the good; what justifies these regulative principles above all is not that they maximize the social welfare or otherwise promote the good, but rather that they conform to the concept of right, a moral category given prior to the good and independent of it.
\end{abstract}

Liberalism and the Limits of Justice, $2 \mathrm{~d}$ ed. (Cambridge: Cambridge University Press, 1998) at 1 [emphasis in original].

14 As Jonathan Chaplin suggests, "liberal democracies rarely, if ever, impose explicit constitutional or legal restraints on employing [religious-based] arguments." Therefore, Chaplin focuses on the "moral and political legitimacy" accorded to different kinds of arguments. Supra note 11 at 618

15 Audi \& Wolterstorff, supra note 2 at 17 . We would suggest that the reference to coercive laws and policies does not limit Audi's position greatly, since in the final analysis, all law would seem to contain a coercive element. On Audi's and Rawls' descriptions of the virtuous citizen, Wolterstorff makes the rather caustic response: "No matter what principles of justice a particular political theorist may propose, the reasonable thing for her to expect, given any plausible understanding whatsoever of 'reasonable and rational,' is not that all reasonable and rational citizens would accept those principles, but rather that not all of them would do so. It would be utterly unreasonable for her to expect all of them to accept them." Audi \& Wolterstorff, supra note 2 at 99 [emphasis in original].

16 Rawls, supra note 11 at 223-30.

17 Richard Rorty, Philosophy and Social Hope (London: Penguin Books, 1999) at 170-71 [Rorty]. Paul Horwitz, supra note 9 at 27-28, sees Rorty's comments revealing "a defensiveness about the future of the liberal project itself and the future of the state 
The liberal positions on this issue differ in various ways. ${ }^{18}$ Some argue for constraints on all religious argument in the public square ${ }^{19}$ others, like Rawls, would restrict religious argument only when it is used to advocate or decide certain fundamental matters. Still others would permit religious argument, but only if the speaker is willing and able to make the same point using non-religious argument. ${ }^{20}$ Some argue for the exclusion of religious arguments only; others for all arguments grounded in comprehensive philosophies. What unites these positions is a common belief that religious reasons should not be relied upon when political issues are being decided in a liberal democracy. ${ }^{21}$

Proponents of exclusion argue that to allow religious argument in the public square is divisive or potentially divisive, and also in some way unfair or disrespectful to those who do not share the religious belief. These reasons are unpersuasive. It also appears that the liberal position is committed to an Enlightenment epistemology that has been largely discredited in the modern and postmodern world. In addition, public reason as conceived by Rawls and others does not generate sufficient principles to resolve public policy debates. An appeal to fundamental presuppositions usually grounded in some

... betray[ing] a view that beliefs and concepts that cannot be understood in a rational manner represent threats both to reason and to its offspring, liberal democracy."

18 Audi \& Wolterstorff, supra note 2 at 72 and following.

19 Jonathan Chaplin labels this position as "classical secular liberalism," and describes it as follows: "[R]eligiously-based arguments, while legally permitted, are incompatible with the requirements of a liberal democratic political morality; virtuous citizenship implies accepting the exclusion of religion from the public square and relying only on arguments which, supposedly, are equally accessible to all citizens - variously termed 'public,' 'secular,' 'common,' 'reasonable,' or 'rational.' In a religiously pluralistic culture, such arguments by definition cannot be religiously-based." Chaplin, supra note 11 at 626 .

20 Chaplin (ibid. at 626-27) refers to this as the "inclusive" secular view. Under this view, "religiously-based arguments may quite freely be used to support proposals regarding law or public policy" but "only on the condition that, in addition to whatever religiously-based arguments they [religious believers] may wish to advance, they must also advance (or stand ready to advance) arguments which do not in any way depend on religious belief. It is these non-religious arguments which turn out to carry the necessary public legitimacy in governing debate and especially decision; religiously-based arguments play, at best, a supporting public role" [emphasis in original].

21 Audi \& Wolterstorff, supra note 2 at 75. religious or comprehensive belief seems inevitable.

\section{ARGUMENTS FOR EXCLUSION BASED ON ALLEGED DIVISIVENESS}

One argument for excluding religious argument is that it is divisive. ${ }^{22}$ The issue of whether religion is a beneficial or corrosive force in society is much debated, and it will not likely ever be resolved. The debate turns as much on the historical facts as it does on one's views about religion. A fair conclusion is that religion's impact has been at times divisive, at times beneficial, at times neutral.

There are those who would argue that public policy must be protected from religious influence because religious beliefs are inherently irrational or repressive and would lead inevitably to irrational or repressive laws. Thus, Duncan B. Forrester suggests that " $[t]$ here is a widespread and deep-seated conviction in the modern western academy that religion is either a trivial or a malign factor in political life." 23 Certainly it is not difficult to find numerous examples, whether historical or present-day, where religion has been used as an excuse for violence and oppression or where religious institutions have supported, or at least not actively resisted, violent and oppressive regimes or policies. Others, though, would make the opposite argument. Thus, Harold J. Berman suggests that religion has influenced the law "in the direction of greater humanity," 24 and John von Heyking argues that "[r]eligion helps liberal

22 See, for example, William P. Marshall, "The Other Side of Religion" (1993) 44 Hastings Law Journal 843.

23 Forrester, supra note 3 at 26 . This conviction is sometimes used as a basis for arguing that religious- based discourse should be excluded from the public square. This contention requires a response at two levels. First, it hardly seems acceptable to delegitimize a particular kind of public debate simply because it might be used by those whose politics we disagree with. Second, the underlying premise cannot be sustained. This becomes very clear if we move from theory to how people actually debate social issues. When we do so the role of religious belief on both sides of many contentious issues becomes obvious. No religion is internally homogenous and in Canada religious pluralism is increased by the presence of a number of different faith traditions.

24 Berman, Law and Revolution, supra note 3 at 168. 
democracy at its weakest point by elevating it from its characteristic vices." 25

The plethora of examples on both sides of this argument underscores the fact that even if we were all agreed on a definition of the just society, there could never be agreement as to whether the influence of religion has consistently moved us closer to, or farther from, attaining that goal. Surely, this should hardly be surprising. Within any religion there will be significant divergence as to what God's will is and how this should be translated into societal relationships. Given the spectrum of religious beliefs, there will be individuals of faith making religious-based arguments on both sides of almost any issue. Thus, for example, while it is accurate to point to the religious inspiration behind the American abolitionist and civil rights movements, ${ }^{26}$ at the same points in history there were church-goers who viewed slavery or segregation as reflecting God's ordering of the universe.

Moreover, an important distinction can often be drawn between a religious institution and individual voices within it. Thus, in evaluating the response of the church to, for instance, the Holocaust, do we look at individuals such as Dietrich Bonhoeffer, or at the stance of the Catholic and Lutheran churches as institutions in Nazi Germany? Do we look at the words and actions of Archbishop Desmond Tutu, or of the Christian Reformed Church in apartheid South Africa? Do we consider the work of Latin American Archbishop Oscar Romero, or the more conservative Roman Catholicism prevalent in Latin America? Nor can it be assumed that the church as institution will always take a more conservative stance than individuals within the institution. The policy of the United Church of Canada on gay and lesbian ordination and on same-sex marriages is far less traditional than the

25 John von Heyking, "The Harmonization of Heaven and Earth? Religion, Politics, and Law in Canada" (2000) 33 University of British Columbia Law Review 663 at 673. Similarly, Horwitz (supra note 9 at 55) argues for a recognition of the "intrinsic value of religion." Our position would probably be more akin to Karen Armstrong's, who points out that religion has often been "cruel and coercive," yet "[a]t its best (and only at its best) religion had helped people to cultivate an appreciation of the holiness of humanity." The Battle for God (London: Harper Collins Publishers, 2000) at 199-201.

26 Audi \& Wolterstorff, supra note 2 at 80. views of at least some of those in the pews. No religion is monolithic, and religion is far too varied and complex to allow for any simplistic generalizations about how faith and politics will interact.

It is arbitrary and unprincipled to exclude religious argument because of its divisiveness. What beliefs are not potentially or actually divisive? It has become something of a stock argument to note the carnage of past religious wars and to use that history as proof of religion's danger to a modern liberal democracy. In the twentieth century, however, non-religious belief systems, often hostile to religion, such as Marxism, Communism, and Nazism led to the deaths of hundreds of millions of people in countless wars and acts of genocide. One of the many lessons of the past century is that beliefs of any kind have the potential to create discord.

Almost any public policy issue, regardless of the terms on which it is discussed and debated, can give rise to conflicts. Taxation, Aboriginal rights, the decriminalization of drugs, Québec independence, gun registration, etc., have each caused social friction and sometimes violence. Furthermore, this dissension can occur even when those on opposite sides do not make any explicit references to comprehensive value systems. Consider a hypothetical example: You and I may both believe in helping the less fortunate in society, and each of us may ground our belief in a non-comprehensive philosophy. But there is ample room for serious disagreement between us on how to help the poor. Suppose that you support a laissez-faire, market-driven, corporate agenda; I favour interventionist economic strategies that closely regulate and constrain corporate policies and also tax the rich heavily. My position flows from a belief, supported by historical and sociological studies, about the relationship between poverty and business corporations in North America. Yours is grounded in a devotion to a particular reading of Adam Smith and his modern disciples, such as Milton Friedman. Neither of us makes any arguments grounded in religious belief; indeed, we do not intend an appeal to any comprehensive philosophies whatsoever. Each supports our position with arguments we consider empirical, reasoned, and scientific. Nevertheless, this sort of disagreement 
and argument has been exceptionally divisive in the rich, Western world and has often led to violence in the past few decades. One only has to recall the violence at the Québec Summit of the Americas in April 2001 to realize that positions of any kind, strongly held, can lead to division and sometimes civil unrest. ${ }^{27}$

Even if someone takes a position explicitly based on religious beliefs, this does not necessarily make it more divisive than arguments based on other comprehensive philosophies. If an individual makes an argument about a particular law or public policy, and links that argument to his or her religious beliefs, some listeners will agree with the public policy stance but not with the religious reasoning; others will disagree with the speaker's position on that particular issue but see the references to religion as valid; a third group will agree with both aspects; and a fourth group will reject everything the speaker says. Does this make the reference to religion exclusionary or divisive? It is difficult to think of secular arguments, buttressed with reference to a particular secular ideology, that would not meet the same four-fold response. As Jonathan Chaplin has pointed out, perspectives grounded in secular philosophies do not enjoy anything close to universal support and are frequently at odds with each other on significant public policy issues. ${ }^{28}$

If certain sorts of arguments are going to be excluded because they are divisive, it appears that the public square will be bereft of almost any argument and debate, save for the most banal exchange of narrow platitudes. The liberal position assumes an ideal society of citizens who share common political principles of sufficient richness and complexity to address the thorny public policy issues of the day. Unfortunately, someone relying solely on public reasons cannot resolve even the most basic policy debate. Assume agreement on Rawls' two fundamental liberal

27 Violent chaos broke out in Québec City when protesters representing environmental, labour, and human rights organizations clashed with police while protesting the free trade talks being held by representatives of numerous countries of the Americas. The protesters opposed the Free Trade Area of the Americas because of a belief that it would hurt the poor. See for instance, "Summit of the Americas," online: The Globe and Mail <http://www .theglobeandmail.com/serials/summit 2001/>.

28 Chaplin, supra note 11 at 640 . principles of legitimacy. ${ }^{29}$ For example, suppose agreement on the principle of legitimacy that the government should treat all persons as free and equal. How does that principle resolve an issue such as the distribution of resources within society, given the various ways that wealth can be distributed? Kent Greenawalt discusses the various approaches that could be used:

Among the most familiar are the Marxist formula, "From each according to his abilities, to each according to his needs," the utilitarian principle of maximizing average or total welfare, and the suggestion of Rawls that distribution should be equal except as inequality will increase goods for representative members of the least advantaged economic group. In different respects each of these views treats all citizens as equal. For Marx, each's needs count equally; for the utilitarian, each's capacity for happiness (or some surrogate) counts equally in the search for maximum overall welfare; for Rawls, each's entitlement to resources in a fundamental sense is equal and inequalities are allowed only if everyone is made better off.

A choice among these and other distributive approaches will depend on some initial premise about proper notions of human equality and upon complex judgments about human nature and actual or potential social relations. ${ }^{30}$

Rawls' principles of legitimacy must be informed at every turn by other more fundamental assumptions about reality. This is another reason why religious and other comprehensive

9 Rawls' two principles of justice are: Each person has an equal claim to a fully adequate scheme of equal basic rights and liberties, which scheme is compatible with the same scheme for all; and in this scheme the equal political liberties, and only those liberties, are to be guaranteed their fair value. Social and economic inequalities are to satisfy two conditions: first, they are to be attached to positions and offices open to all under conditions of fair equality of opportunity, and second, they are to be to the greatest benefit of the least advantaged members of society. Supra note 11 at 5-6.

30 Greenawalt, Religious Convictions, supra note 11 at 174 [footnotes omitted]; see also, Audi \& Wolterstorff, supra note 2 at 103 
philosophies should not be, indeed cannot be, excluded from public discourse. They are often relevant (and sometimes necessary) for the resolution of many issues of concern in a liberal democracy.

Unless we believe that all arguments about what is right or wrong in a particular situation are either completely arbitrary or completely motivated by self-interest, then we have to accept that when people talk about various policy options as good or bad, they are measuring the options against a larger sense of right and wrong - in other words, against some sort of theory of justice, however incompletely expressed. Even those who reject all religious beliefs would be hard pressed to articulate a vision of justice without reference to some underlying set of beliefs - whether humanism, feminism, Marxism, liberalism, conservatism, or libertarianism - that are also based on ultimately unverifiable assumptions, in the same way as religious beliefs.

The liberal position inevitably must espouse the truth of certain propositions, such as the equality of all people or the fundamental value of human freedom. A religious person might espouse the importance of worshipping God. To argue for the truth of these propositions both parties must assert non-empirical presuppositions, beliefs about the nature of reality. Even those who claim to disavow underlying foundational beliefs still seem to have fairly clear ideas about what kind of society we should be trying to create - a concept of the good that seems to be based on faith assumptions about how we should and should not treat our fellow human beings. As Moon argues, "At root, public debate and decision-making is about issues of fundamental value. Moreover, as many others have pointed out, so-called secular values have a religious pedigree, and a transcendent or faith-based character.,"31

\section{ARGUMENTS FOR EXCLUSION BASED ON ALLEGED UNFAIRNESS}

Religious arguments are sometimes said to be unfair because they are inaccessible to those who

$31 \quad$ Supra note 8 at 573. do not hold the religious belief. ${ }^{32}$ Thus, Richard Rorty claims that " $t]$ he main reason religion needs to be privatized is that, in political discussion with those outside the relevant religious community, it is a conversation-stopper. ${ }^{, 33}$ But is this really the case? Suppose someone argues in favour of protecting the environment because, according to the Book of Genesis, humanity is responsible for safeguarding God's creation, the earth. This is an argument from authority. Leaving aside the fact that these sorts of arguments are unlikely to be persuasive to someone who does not accept the authority of the Bible, or this particular interpretation of it, why is it unfair to someone who does not share the same religious belief or any religious belief at all? Is it inaccessible to that person, and if so in what sense?

It does not seem to be inaccessible, even to someone who does not accept the Bible as authority. The appeal to the authority of Scripture is no different than an appeal to any authority, religious or otherwise. It is an assertion that the source of the knowledge is, in and of itself, grounds for accepting the argument, or at least grounds for giving it serious consideration. Arguments from authority are well-known rhetorical strategies, common in discussion and debate.

Is the appeal to religious belief inaccessible in the sense that it is incomprehensible? For someone who has not read the first few chapters of Genesis, the meaning of the argument may be unknown but is surely not unknowable or incomprehensible. The Bible is available for reading and study to anyone, as are the Koran and other religious texts. The person making the argument could be asked to explain its meaning in non-religious language. Non-believers can be as knowledgeable about religious arguments as believers, and often are. Someone who is unfamiliar with arguments grounded in supply-side economic theory, put forward by an economist who believes in that particular theory, is in the same position as someone who is met with the argument that humanity is the God-appointed steward of the

\footnotetext{
See e.g., Kent Greenawalt, "Grounds for Political Judgment," supra note 11; and Abner S. Greene, "Is Religion Special?" (1994) University of Illinois Law Review 535.

33 Rorty, supra note 17 at 171.
} 
earth. Each will, if they so choose, need to gain a better understanding of the argument by familiarizing themselves with the appropriate texts or by asking questions.

Are religious arguments incomprehensible in the sense that a non-believer cannot understand the basis for the belief - e.g., faith in God or faith in a religious text? While it may be true that there is a sort of psychological separation or divide between a believer and a non-believer (the believer has faith in the particular thing or person, the non-believer does not), anyone can understand the nature of faith in some sense because everyone (or seemingly everyone) has at least at one time or another had faith in someone or something. The non-believer can therefore come to an understanding of a believer's faith by analogy. ${ }^{34}$ If, therefore, the substance of the belief is not inaccessible (e.g., humanity as stewards of God's world) and the faith basis of the belief is accessible by analogy, it is hard to countenance the argument that religious argument is inaccessible to the non-believer. ${ }^{35}$

Even if religious arguments are in some way inaccessible, it does not follow that they should therefore be excluded from the public square. There is always the possibility that the person who finds the religious argument inaccessible will find a means of access or understanding, or if not, will simply give the argument no weight, thereby eliciting and requiring alternative arguments. Such

34 The classic definition of faith in the Christian New Testament is found at Hebrews 11:1, where faith is described as "the confidant assurance that what we hope for is going to happen." Mark R. Norton, ed., Holy Bible, New Living Translation (Wheaton, IL: Tyndale House, 1996).

35 In fact, we would suggest that, even for those who do not themselves subscribe to religious beliefs, a recognition of the religious aspects of many social issues would seem to be necessary for those involved with politics or the law. By way of example, consider a case where parents have made a decision to refuse conventional medical treatment for their ill child, and that decision is being challenged by the state. Suppose the parents reject the premises underlying conventional Western medicine and are wholehearted disciples of some alternative approach to treatment. While it is certainly not necessary for the lawyers and the judge involved in the case (or for those crafting a legislative response to such a case) to embrace the same philosophy of treatment, it seems obvious that they will be better able to represent the parents, respond to the parents' arguments, decide the case, or draft effective legislation if they have some understanding of (even if not agreement with) the premises on which the parents based their decision. is the nature of debate and discourse, even debates where religious arguments are excluded.

\section{ARGUMENTS FOR EXCLUSION BASED ON ALLEGED DISRESPECT}

Is it disrespectful to support a political decision for reasons that not all citizens accept as appropriate? A Buddhist, for example, might support a particular environmental policy because her religious teachings tell her that all life is sacred. Is the Buddhist being disrespectful to those who do not share and perhaps cannot comprehend the basis for her political decision? A central claim of the liberal position is that citizens should not, out of respect for every citizen's freedom and equality, rely on reasons for their decisions they could not expect these fellow citizens to endorse. If the environmental policy is given the force of law by the state, then some citizens are subject to the coercive power of the state for reasons they find unacceptable. ${ }^{36}$ Is this disrespectful?

One response to this argument is to ask what the ethic of respect requires. ${ }^{37}$ It is certainly not self-evident that a citizen in such a situation has been treated disrespectfully. Nor is it self-evident that a liberal democracy requires that citizens respect other citizens in this way. The liberal position assumes a definition of respect that is contested. By contrast, why should we not begin with the assumption that it is disrespectful to ask the Buddhist to justify her decision on grounds acceptable to all citizens? Why privilege the idea of public reasons? Wolterstorff wonders whether appropriate respect is being paid in the following situation:

Suppose that you offer to me reasons derived from your comprehensive standpoint; and that I, fully persuaded of the moral impropriety of such behaviour by the advocates of the liberal position, brush your remarks aside with the comment that in offering me such reasons, you are not paying due respect to my status as free and equal. Only if you

\footnotetext{
Rawls, supra note 11 at 217-18.

Audi \& Wolterstorff, supra note 2 at 109
} 
offer me reasons derived from the independent source [public reasons] will you be paying me due respect. To offer me such reasons is to demean me; I will not listen. ${ }^{38}$

Is the adherent of the liberal position being respectful here? The ethic of respect may require that I listen to others in their particularity, and permit them to make political decisions that are supported by their particular beliefs, rather than requiring them to appeal to public reason. ${ }^{39}$

A second response is to question the assertion that political decisions are not legitimate when based on religious or other comprehensive beliefs. Many, perhaps most, citizens in a liberal democracy hold that political legitimacy is satisfied when, after a full and fair debate that was open to all citizens, a majority of citizens vote in favour of a policy or in favour of a government that develops a particular policy. ${ }^{40}$ This procedure forms the bedrock of liberal democracies and to most citizens is considered reasonable and fair. ${ }^{41}$ It is a way of making political decisions that accommodates and reflects the plural and multifaceted nature of the citizenry in Western democracies. It accords also with the very nature of discussion and debate, which inevitably involves a clash of opposing and divergent points of view. Differences in political discussions, like debate of any kind, usually turn not on a disagreement over facts or the logic of an argument, but on fundamental disagreement about

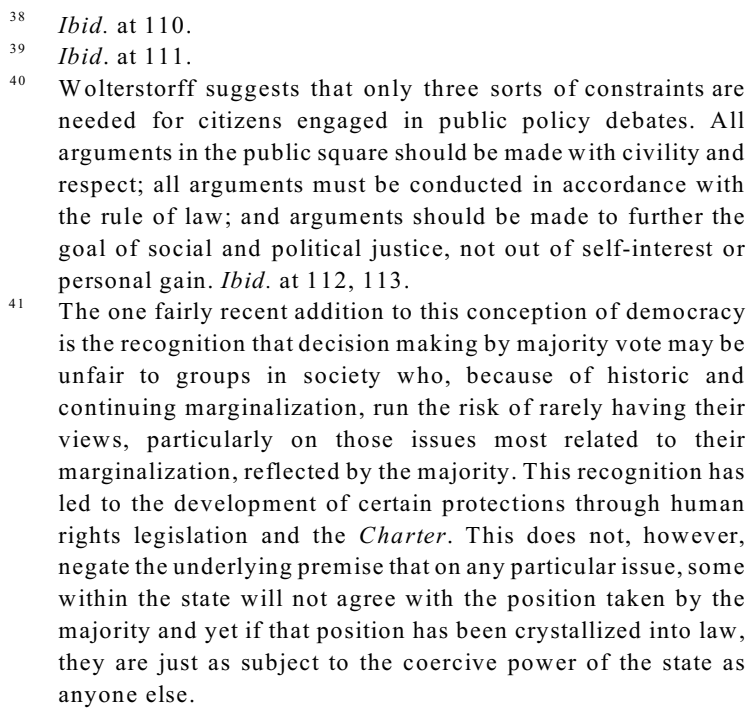
needed for citizens engaged in public policy debates. All arguments in the public square should be made with civility and respect; all arguments must be conducted in accordance with the rule of law; and arguments should be made to further the goal of social and political justice, not out of self-interest or personal gain. Ibid. at 112, 113 .

${ }^{41}$ The one fairly recent addition to this conception of democracy is the recognition that decision making by majority vote may be unfair to groups in society who, because of historic and continuing marginalization, run the risk of rarely having their views, particularly on those issues most related to their marginalization, reflected by the majority. This recognition has led to the development of certain protections through human rights legislation and the Charter. This does not, however, negate the underlying premise that on any particular issue, some within the state will not agree with the position taken by the majority and yet if that position has been crystallized into law, they are just as subject to the coercive power of the state as anyone else.

basic assumptions. Once the disputants have determined that neither has committed an error of logic and each has a clear apprehension of the facts, the debate must inevitably turn to basic assumptions if one side is to prevail in persuasion over the other. No one in this day and age should ever expect to find widespread agreement over basic assumptions. Pleas to limit arguments to those with which any reasonable person could agree assume the possibility of finding universally held positions and fail to recognize that the very concept of reasonableness is contested.

\section{ARGUMENTS FOR EXCLUSION RELATED TO CONSTITUTIONAL CONCERNS}

Another argument against the use of religious arguments to justify political decisions takes a constitutional form. It is two-pronged. It is said that the use of religious reasons to support public policy is contrary to freedom from religion, and, further, that religious arguments that become law represent the "establishment" of religion within the state. ${ }^{42}$

Moon summarizes the relevant constitutional protection under the Canadian Charter of Rights and Freedoms:

The Canadian Charter of Rights and Freedoms guarantees to all persons "freedom of conscience and religion." The Charter, however, does not include any obvious equivalent to the Establishment Clause of the First Amendment of the United States Bill of Rights. According to the Canadian courts, s. 2(a), the freedom of religion provision in the Charter, protects the individual from "coercion in matters of conscience." It prohibits the state from either restricting or compelling religious practice. But it does not necessarily preclude state support for religion. State support for the practices or institutions of a particular

42 For a discussion of the s. 2(a) jurisprudence, see Horwitz, supra note 9 . He argues (at 6) that "the proper approach of the courts and the state to religion should be both supportive and accommodating." 
religion will breach s. 2(a) only if it coerces some members of the community, and interferes with their ability to practice their faith or compels them to practice the favoured religion. ${ }^{43}$

The Charter may render unconstitutional laws that adopt religious symbols as symbols of the state, mandate prayer in schools, interfere with the practice of religion, or prohibit certain activities for a primarily religious reason. ${ }^{44}$ Certainly, as Moon concludes, "[t]he State should remain neutral on the issue of what is the true faith. It should not prefer one religion over another." 45 This is very different, however, from the question of whether commitment to liberal democracy requires one to eschew religious-based arguments on matters of public policy.

Is it contrary to the Charter guarantee of "freedom of conscience and religion" for a citizen to base decisions concerning public policy on religious grounds? Clearly, the answer on this question is no. There is no legal or constitutional constraint on the reasons she uses to justify her decisions. There are, of course, constraints on how one may express that religious reasoning. In Ross v. New Brunswick School District No. $15,{ }^{46}$ the Supreme Court of Canada held that the freedom of an individual to express her religious beliefs is not unlimited "and is restricted by the right of others to hold and to manifest beliefs and opinions of their own, and to be free from injury from the exercise of the freedom of religion of others." The Court concluded that "[i]n relation to freedom of religion, any religious belief that denigrates and

$43 \quad$ Supra note 8 at 563

44 See, for example, R. v. Big M Drug Mart, [1985] 1 S.C.R. 295 , online: CanLII <http://www.canlii.org/ca/cas/scc/1985/ $1985 \mathrm{scc} 15 \mathrm{html}>[$ Big $M]$, regarding Sunday closing legislation. Yet, it should be noted that, in striking down a law that required stores to remain closed on Sunday, the Supreme Court of Canada considered the impact of such laws not only on those who hold no religious beliefs but also on those whose religions have as their holy day a day other than Sunday. As Benjamin Berger suggests, this indicates that "the Court [was] plainly motivated by a pluralist vision of secularism" - a vision that did not relegate religion to the sidelines. "The Limits of Belief: Freedom of Religion, Secularism, and the Liberal State" (2002) 17 Canadian Journal of Law \& Society 39 at 56 . For another critical reading of Big $M$, see Horwitz, supra note 9 .

45 Moon, supra note 8 at 573

46 [1996] 1 S.C.R. 825, online: CanLII <http://www.canlii.org/ca/ cas/scc/1996/1996scc35.html $>$ [Ross $]$.

47 Ross, ibid. at para. 72. defames the religious beliefs of others erodes the very basis of the guarantee in s. 2(a) - a basis that guarantees that every individual is free to hold and to manifest the beliefs dictated by one's conscience." 48 Thus, while we argue that public reliance upon religious reasoning should be recognized as legitimate, we also acknowledge (and in fact support) the constitutional constraint that beliefs or values - whether religious or otherwise - are not to be expressed in ways that diminish others' freedom of belief or that denigrate the essential humanity of others.

\section{ARGUMENTS FOR EXCLUSION BASED ON EPISTEMOLOGICAL GROUNDS}

It appears that the real weight of constitutional, philosophical, and other arguments for excluding religious-based arguments rests on epistemological grounds - on the assumption that a coherent and relevant distinction can be made between the secular world and the religious world. Thus, the liberal position assumes that it is possible for a citizen to be "free from religion," for religion and faith to operate in the private realm, and for reason or "non-religious values" to hold sway in the secular, public world. On this view of the world, any incursion into the public square of religious reasons or law based on religious values is impermissible and inappropriate.

While it is certainly possible to be free not to practice religion and to create a public space free of religious symbols and practices (and the Charter protects those rights), it is not possible for the secular realm to be free of metaphysical beliefs, some of which are religious. As Benson explains:

The term "secular" has come to mean a realm that is neutral or, more precisely, "religion-free." Implicit in this religionfree neutrality is the notion that the secular is a realm of facts distinct from the realm of faith. This understanding,

48 Ibid. at para. 94. For a discussion of this issue, see David M Brown, "Freedom From or Freedom For: Religion as a Case Study in Defining the Content of Charter Rights" (2000) 33 University of British Columbia Law Review 551 at 599. 
however, is in error.... States cannot be neutral towards metaphysical claims. Their very inaction tow ards certain claims operates as an affirmation of others. This realization of the faith-based nature of all decisions will be important as the courts seek to give meaning to terms such as secular in statutes written some time ago. $^{49}$

On this issue, it is relevant to consider a recent decision of the Supreme Court of Canada, Chamberlain v. Surrey School District No. 36. ${ }^{50}$ Chamberlain involved judicial review of a decision of a school board to prohibit three books on same-sex parenting from being used in the classroom. This prohibition was clearly based on the religious beliefs of the school board members. The relevant legislation ${ }^{51}$ required school boards to act in a "secular" and "non-sectarian" fashion. The majority of the Supreme Court of Canada found the school board's decision unreasonable and remanded the issue of whether the books should be approved to the board. The Court noted that in light of the legislation, "the school board must consider the interests of all its constituents and not permit itself to act as the proxy of a particular religious view held by some members of the community, even if that group holds the majority of seats on the board."52 However, the Court was very clear that:

[t]he Act's insistence on strict secularism does not mean that religious concerns have no place in the deliberations and decisions of the Board. Board members are entitled, and indeed required, to bring the views of the parents and communities they represent to the deliberation process. Because religion plays an important role in the life of many communities, these views will often be motivated by religious concerns. Religion is an integral aspect of

49 Iain T. Benson, "Notes Towards a (Re)definition of the 'Secular'" (2000) 33 University of British Columbia Law Review 519 at 520 . On this issue of the definition of the term secular and its relationship to religious belief, see also Chaplin, supra note 11; von Heyking, supra note 25; and Berger, supra note 44

$50 \quad$ Chamberlain, supra note 7

s1 School Act, R.S.B.C. 1996 c. 412 , as amended, s. 76

Chamberlain, supra note 7 at para. 27. people's lives, and cannot be left at the boardroom door. What secularism does rule out, however, is any attempt to use the religious views of one part of the community to exclude from consideration the values of other members of the community. A requirement of secularism implies that, although the Board is indeed free to address the religious concerns of parents, it must be sure to do so in a manner that gives equal recognition and respect to other members of the community. ${ }^{53}$

This statement suggests that the Supreme Court of Canada is developing a nuanced understanding of the concept of "secular," which legitimates, but does not privilege, arguments based on religious belief.

In another recent case, Trinity Western University v. British Columbia College of Teachers, ${ }^{54}$ the Supreme Court of Canada recognized that religious values are interwoven in the fabric of Canadian society, and it implicitly rejected a simplistic separation or division of the secular and the religious. Trinity Western involved judicial review of a decision of the B.C. College of Teachers. The College had refused Trinity Western University certification for its teacher education program because students were required to sign a "community standards" document agreeing to refrain from various "un-Biblical" behaviours, including homosexuality. In the course of its discussion, the majority of the Supreme Court of Canada commented: "The diversity of Canadian society is partly reflected in the multiple religious organizations that mark the societal landscape and this diversity of views should be respected." 55

It is useful to situate this discussion in the broader historical and philosophical context. The period of the Enlightenment exposed and exacerbated a developing rift between science and religion. "The fundamental axiom of

53 Ibid. at para. 19. For a discussion of the approach taken by the lower courts in Chamberlain, see Berger, supra note 44. See also Brown, supra note 48.

${ }^{54}$ Trinity Western, supra note 7.

55 Ibid. at para. 33 . 
Enlightenment thought was that the world could be understood through the objective application of reason and science once the distorting influence of religious ideologies was overcome." 56 Over the years, the secular became the domain of reason and objective truth, publicly verifiable; religion was relegated to the margins of individual belief, either unprovable or untrue.

A critical assumption of the liberal position on the issue of religious discourse in the public square is that a form of human reason exists that enjoys a different epistemological basis - a superior grounding in truth - than religious belief, which therefore justifies the exclusion of religious argument from the public square. Rawls' position is typical of the liberal position because he appears to rely on a conception of human reason in the Lockean Enlightenment sense, a reason that somehow transcends human experience and that, functioning properly, will lead to agreement and consensus on fundamental matters. ${ }^{57}$ The liberal epistemology is at odds with the postmodern perspective, which, as described by Richard Tarnas, reflects an "appreciation of the multidimensional nature of reality, the manysidedness of the human spirit and the multivalent, symbolically mediated nature of human knowledge and experience. ${ }^{n 8}$

In Chamberlain, the Supreme Court of Canada appeared to recognize that almost all arguments that are made for or against a particular public policy are likely to be rooted in a larger complex

56 Frederick Gedicks, "The Religious, the Secular and the Antithetical." Supra note 11 at 127.

57 As Larry Alexander writes: "The liberal's rejection of religiousbased policies suggests some sort of epistemological divide or discontinuity between what we can claim justifiably to know secularly so to speak, and what we can claim justifiably to know religiously, the latter being an inferior form of knowledge for purposes of public policy." Supra note 11 at 774. The liberal position would appear to reflect what Perry (Love and Power, supra note 1 at 57) describes as the "correspondence" theory of rationality, according to which the truth of a statement or belief can be ascertained by determining how closely it corresponds to "unmediated reality." Supra note 1 at 57 . In rejecting this approach, Hilary Putnam has stated, "If one must use metaphorical language, then let the metaphor be this: the mind and the world jointly make up the mind and the world," quoted in Perry, ibid. at 59. See also Audi \& Wolterstorff (supra note 2 at 96 and following) for a short critique of Rawls on this point.

58 Richard Tarnas, The Passion of the Western Mind: Understanding the Ideas That Have Shaped Our World View (New York: Ballantine Books, 1991) at 407. of values and beliefs. Elaine Pagels notes, for example, that divergent conceptions about the proper role of the state can often be traced to different assumptions about human nature. ${ }^{59}$ These assumptions may inform our religious discourse (God made humanity good according to the creation myth in the Book of Genesis; or conversely, humanity is flawed, according to a different interpretation of the same text). Or these fundamental assumptions may inform other forms of discourse, such as political philosophy (followers of Rousseau see natural human goodness corrupted by society; other traditions following philosophers such as Hobbes advocate societal structure to constrain human impulses, which they believe tend to disorder and chaos when unfettered). ${ }^{60}$

A fundamental assumption about human nature (or whether there is such a thing as human nature) is beyond conclusive empirical proof. We may hold these sorts of beliefs or assumptions for a variety of reasons: our psychological makeup; what our parents taught us; what we learned in church, synagogue, mosque, or temple; our unique life experience; etc. Nevertheless, these assumptions affect how each of us understands and explains the world; these beliefs inform what we call human reason. These beliefs and assumptions are interwoven both into the fabric of the individual citizen and the fabric of Canadian society. The Supreme Court of Canada noted in Trinity Western that the diversity of Canadian society is "partly reflected" in its religious organizations. We would add also in its citizens who hold religious beliefs. It has always has been impossible to separate religious belief and secular reason, because "our common human reason is always a programmed human reason; what we come to believe by the use of our reason (whatever Rawls might have in mind by that) is a

59 See the transcript of Bill Moyers' interview with Pagels in Bill Moyers, A World of Ideas (New York: Doubleday, 1989) at 377.

60 Jean-Jacques Rousseau, The Social Contract, ed. by Susan Dunn (New Haven: Yale University Press, 2002); and Thomas Hobbes, Leviathan (Oxford: B. Blackwell, 1946). Also see R.S. Peters' article on Rousseau in Paul Edwards, ed., Encyclopedia of Philosophy, Vol. 7 (New York: Macmillan Publishing \& The Free Press, 1972) 218; Ronald Grimsley's article on Hobbes in ibid., Vol. 4, 30; and Michael Levin, "Social Contract" in Philip P. Weiner, ed., Dictionary of the Hisotry of Ideas, Vol. 4 (New York: Charles Scribner \& Sons, 1973) 251. 
function, in part, of what we already believe. And we differ in our belief - differ in particular, now, in our comprehensive perspectives." ${ }^{\prime 1}$

\section{CONCLUSION}

The modern Western liberal democracy thrives on a diversity of ideas and vigorous debate. We agree with Veit Bader that rather than prohibiting certain sources of public discourse "we should try to tell the 'whole truth' as we see it on whatever topic and whenever it makes sense, accept that others do the same on an equal footing, tell it in understandable language, and discuss it in a civilized way." 62

The "whole truth" for many citizens cannot be told without an appeal to their religious beliefs. This is hardly surprising, given that the fundamental values of the Western legal tradition are firmly rooted in religious doctrines of past centuries. And, of course, the fact that many, if not most, citizens in Canada and the West are still committed in various ways to a religion makes it inevitable that these beliefs would inform their social and political discussions. Issues such as same-sex marriage and the right to die have, for many people, important religious dimensions. Anyone who wants to fully participate in a discussion of these issues must therefore understand this religious dimension. Rather than try to exclude religious argument from the public square, we should welcome a rich diversity of ideas from a multitude of different perspectives.

\section{David Blaikie}

Assistant Professor

Faculty of Law, Dalhousie University

david.blaikie@dal.ca

\section{Diana Ginn}

Associate Professor and

Associate Dean, Academic

Faculty of Law, Dalhousie University

d.ginn@dal.ca

\footnotetext{
${ }^{61}$ Audi \& Wolterstorff, supra note 2 at 98.

${ }^{62}$ Veit Bader, "Religious Pluralism: Secularism or Priority for Democracy?" (1999) Political Theory 597 at 618.
} 